\title{
The Influence of Economic Factors on the Value Relevance of Accounting Information in Jordan
}

\author{
Dhiaa Shamki ${ }^{1}$ \\ ${ }^{1}$ Department of Accounting and Information Technology, Cihan University Sulaimaniya, Sulaimaniya, Iraq \\ Correspondence: Dhiaa Shamki, Department of Accounting and Information Technology, Cihan University \\ Sulaimaniya, Sulaimaniya, Iraq. Tel: 964-077-1564-6380. E-mail: dhiashamki_iraq@yahoo.com
}

Received: December 17, 2012 Accepted: January 6, 2013 Online Published: February 27, 2013

doi:10.5539/ijbm.v8n6p89

URL: http://dx.doi.org/10.5539/ijbm.v8n6p89

\begin{abstract}
The paper examines the influence of economic factors namely foreign ownership and trading volume on the value relevance of earnings, book value and cash flows relative to three share price proxies namely average annual share price, annual closing share price and share price after a three-month period following the financial year-end (hereafter ATM-share price), after controlling company's size and leverage for Jordanian services and industrial companies within the period 2004-2009. Since the paper is the first, as the researcher believes, that examines the influence of foreign ownership and trading volume on the value relevance of earnings, book value and cash flows in an emerging exchange, it aims to provide evidence regarding the influence of these factors on the value relevance of accounting information. The paper found that the value relevance of earnings and book value is greater for companies having foreign ownership and larger trading volume. With the effect of these factors, closing share price shows more response than the other share price proxies. The findings suggest that market participants might be able to extract the firm value via these economic factors. The paper extends the valuation model by including cash flows together with earnings and book value. The findings demonstrate that there is a shift away from earnings towards book value as the basis of firm valuation.
\end{abstract}

Keywords: value relevance, accounting information, foreign ownership, trading volume, Jordan

\section{Introduction}

Many economic factors can affect the value relevance of accounting information (Anandarajan \& Hasan, 2010; Shamki, 2012). This paper examines the influence of the economic factors (traced by foreign ownership and trading volume) on the value relevance of accounting information (earnings, book value of equity and cash flows from operation) after controlling company's size and leverage. The researcher tries to examine to what extent these factors can influence the value relevance of accounting information for Jordanian services and industrial companies listed in Amman Stock Exchange (hereafter ASE).

It is a fact that the economic environment has a strong influence on accounting since the latter is a service function that operates within an economic framework (Enthoven, 1985). Although Jordan is making progress in opening up the economy and regulatory norms, it is still considered to have a relatively closed economy (Anandarajan \& Hasan, 2010). Therefore, in a developing country, there is a need to examine the influence of the economic factors on the financial accounting and reporting (Dahawy, 2009).

Many studies have examined the influence of the economic factors on the value relevance of accounting information. Bae and Jeong (2007) and Anandarajan and Hasan (2010) examine the influence of foreign ownership on the value relevance of earnings, while Shamki (2012) examines the influence of foreign and local shareholders on the value relevance of earnings and book value. Dontoh, Radhakrishnan, and Ronen (2004) and Liu and Liu (2007) examine the influence of trading volume on the value relevance of earnings and book value. The paper extends these studies by examining the influence of foreign ownership and trading volume on the value relevance of earnings, book value, and cash flows simultaneously that has not been researched before especially in Jordan. The paper's question is: Can foreign ownership and trading volume influence the value relevance of earnings, book value and cash flows in Jordan? Accordingly, the paper objects to examine whether foreign ownership and trading volume can influence the value relevance of earnings, book value, and cash flows. The significance of this study is to examine the influence of trading volume and foreign ownership on the value relevance of earnings, book value, and cash flows simultaneously that has not been examined in Jordan as far as 
the researcher is concerned.

The paper reviews the literature in this area in the next section. Hypotheses development and method are presented in the third section. Findings of the paper are revealed in the fourth section while the discussion and summary are presented in the last section.

\section{Literature Review}

As the more profound and important factors that affected the value relevance of accounting information are the economic factors. For the purpose of this paper, the influence of the economic factors is traced by the influence of foreign ownership and trading volume on the value relevance of earnings, book value, and cash flows.

While investments depend on the transferring of management and capital across national boundaries, foreign investors have been considered as proprietors and not merely lenders (Staley, 1935). In essence, the greater the extent of foreign ownership of a company, the greater is its economic efficiency, (Anandarajan \& Hasan, 2010). Boubakri, Cosset, and Guedhami (2005) found that extending foreign ownership changes the companies' economic efficiency where the greater the extent of foreign ownership leads to greater economic efficiency. Higher proportion of foreign ownership has positive association with company's performance (Claessens, Demirgüç-Kunt \& Huizinga, 2001) and leads to increase the competition environment which will improve the local firm's efficiency and performance (Anandarajan \& Hasan, 2010). This is because foreign investments will introduce advanced information technology (Okuda \& Rungsomboon, 2004) which will reduce operating expenses and increase profits. This will consequently force local companies to double their efforts to keep competitive (Claessens et al., 2001).

According to annual reports of Jordan Securities Commission (JSC), foreign ownership formed about $41 \%$ to nearly $50 \%$ of the ASE total investments within the period from 2004 to 2009. Despite the increased percentage of non-Jordanian (foreign and Arabic) ownership in ASE, few studies examined the influence of this factor on the value relevance of the accounting information in Jordan. Anandarajan and Hasan (2010) pointed out that higher value relevance of reported earnings has been found in Jordan when foreign equity holders in local companies are involved. Shamki (2012) found that extending foreign shareholders number in Jordanian companies has significant influence on the value relevance of individual book value and combined earnings. The paper extends these studies by examining the influence of foreign ownership on the value relevance of earnings, book value of equity, and cash flows from operation in Jordan. Since foreign ownership has strong positive influence on the value relevance of earnings (Bae and Jeong, 2007; Anandarajan \& Hasan, 2010; Shamki, 2012), It is expected that this factor will positively influence the value relevance of book value and cash flows. Foreign ownership as one of the current study's independent variables is measured as whether a company has foreign ownership at the end of financial year (Anandarajan \& Hasan, 2010).

While trading volume is a valuable source of information about assets' value (Kim \& Verrecchia, 2001), prior research found that trading volume play no role as information source about firm value (Admati \& Pfleiderer, 1988; Varian, 1989; Kim \& Verrecchia, 1991; Harris \& Raviv, 1993; Kandel \& Pearson, 1995). If the financial information disclosure is postponed to a later period, trading volume will be used to draw conclusions about the better-informed information on firm value (Verrecchia, 2001; Kim \& Verrecchia, 2001). Beaver (1968) found that earnings announcements led to changes in abnormal price and abnormally high trading. Divergence in earnings pre-disclosure stimulates higher the trading volume than price change (Bamber \& Cheon, 1995). These findings suggest that trading volume is more strongly associated with investors' uncertainty (Callahan, Lee, \& Yohn, 1997).

Dontoh et al. (2004) examined the prediction that declined value relevance of accounting information could be due to increasing trading volume and their results supported the prediction. They found that (1) the value relevance of earnings and book values is negatively associated with the trading volume, (2) a slight decline from $26 \%$ in early 1980 s to $21.8 \%$ in the late 1990 s indicates that a decreasing proportion of trading volume has been explained by the information events, which suggests that there was an increase in the trading volume overtime and, (3) the influence of trading volume on lost firms and profit firms is not significantly different. While Karpoff (1986) concluded that the occurring of the informational events increase the trading volume, Dontoh et al. (2004) concluded that these information events explain a declined portion of trading volume. For Chinese stock market, Liu and Liu (2007) examined the influence of trading volume on the value relevance of earnings and book value and found it statistically insignificant, although Chen, Chen, and $\mathrm{Su}$ (2001) found that with high trading volume, earnings and book value were more value relevant.

In Jordan, trading volume differs among ASE sectors overtime. In industrial sector it is ranging from $12 \%$ in 2006 to $28 \%$ in 2004, while it is ranging from $7 \%$ in 2006 to $47 \%$ in 2005 for services sector (ASE, 2004-2009). 
However, ASE has small trading volume compared with developed markets. This small volume may not allow share prices to fully reflect new information in the market (Chen et al., 2001).

Due to the dramatic changes in trading volumes in ASE within the observed period and since no study examined the influence of trading volume on the value relevance of cash flows especially in Jordan, this paper extends studies of Chen et al. (2001), Dontoh et al. (2004), and Liu and Liu (2007) by adding cash flows from operation as a new variable with earnings and book value to examine the influence of trading volume on the value relevance of these accounting variables in Jordan.

Since trading volume has negative influence (Dontoh et al., 2004), insignificant influence (Liu \& Liu, 2007) on the value relevance of accounting information, positive relationship with price change (Clark, 1973; Epps \& Epps, 1976; Tauchen \& Pitts, 1983) and noisy relationship with price change (Pfleiderer, 1984), there is no clear expectation about the influence of trading volume on the value relevance of earnings, book value, and cash flows in Jordanian companies. Trading volume as one of the current study's independent variables is measured by total number of shares traded of a company at end of the financial year (Cready \& Mynatt 1991; Bhattacharya, 2001).

As referred in prior research, many variables have been found to be controlled when examining the value relevance of the accounting information. Company's size and leverage are the paper's control variables.

Large companies have large book values and large earnings, therefore it is important to control the difference in size among companies (Ota, 2001). Since larger companies are more exposed to the public eye, take less time to report (Dyer \& McHugh, 1975) and more information is available about them, foreign investors tend to have more knowledge about large companies than about small ones (Kang \& Stulz, 1997). This leads to the expectation that less information asymmetry or lower cost of information acquisition will be found between domestic and foreign investors in large size companies (Covrig, Lau, \& $\mathrm{Ng}, 2006$ ). The larger the company size, the lower the information asymmetry degree (Kim \& Yoo, 2009). A negative association has been found between company size and information in the earnings announcement (Bamber, 1986). From the aforementioned discussion, the paper controls company size since it is an important factor related to the company's accounting information availability to reduce information asymmetry. Following Anandarajan and Hasan (2010) who controlled company size to examine the value relevance of earnings for Jordanian companies, the present paper extends their paper by controlling company size to examine its influence on the value relevance of earnings, book value and cash flows for ASE companies. This variable will be measured by log of total assets (Hassan, 2004; Anandarajan \& Hasan, 2010).

Financial ratios are commonly extracted from financial statements including balance sheet, income statement, cash flows, etc. Companies that are financed via debt can be considered as highly leveraged one if the ratio of debt to total assets is increased. This implies more risk which will be associated to the company's operation. Since high levels of debt increase the interest payments (Bronars \& Deere, 1991; Matsa, 2010), too high leverage ratio would make an investment at risk (Myers, McConnell, Peterson, Soter, \& Stern, 1998). Although leverage is a strong predictor for a company's credit rating, companies' investments riskiness is another factor that affects this rating. A company is considered to be having lower credit rating if it has low leverage but a very risky investment than a company with high leverage but more conservative investments. Decreasing a company's leverage could be a wise step to reduce the probability of companies to be in financial distress because when companies cannot fulfill their debt payments, bankruptcy may occur (Verwijmeren \& Derwall, 2010). Company's leverage will be used as a control variable because its risk level is asserted to play a moderating role in accordance with the factors that influence the value relevance of accounting information (Kothari, 2000). This variable will be measured by the ratio of debt to total assets (Anandarajan \& Hasan, 2010).

The paper adopted the theories of valuation, foreign investment, and trading volume in explaining the relationship among its variables. Accurate market price estimation must be produced for any valuation model to have validity. The model should reflect the market culture and conditions at the time of the valuation. It is a must to remember that the model should represent the market underlying fundamentals and that the resulting figure of the valuation is "value" (Damodaran, 2007). The value relevance empirical research has its roots in the equity valuation models' theoretical framework (Vishnani \& Shah, 2008). Ohlson (1995) and Felthman and Ohlson (1995) point out that firm value can be expressed as a linear function of book value, earnings, and other value relevant information. Since the paper focuses on examining the value relevance of the accounting information, price model that used in previous valuation studies is relevant to be adopted.

Sethi, Guisinger, Phelan, and Berg (2003) pointed out that the foreign ownership has been explained in literature by many theories. The earliest explanation was by the capital movements theory (Iversen, 1935), which viewed foreign ownership as a part of portfolio investments (Aliber, 1971). Three distinct theories have been found to be 
the logical intersection for the foreign ownership theory, which are international capital markets theory, international firm theory, and international trade theory (Casson, 1985). Since the paper examines the influence of foreign ownership on the value relevance of accounting information and there is a positive influence of foreign ownership on the value relevance of the earnings (Bae \& Jenong, 2007; Anandarjan \& Hasan, 2010), it is clear that foreign ownership theory is relevant to be adopted in this paper.

Most trading volume theories asserted that investors have different belief revisions that caused trading volume (Barron, 1995). Two basic assumptions are included in these theories, which are: (1) market agents revise their prices in a customary and distinctive manner; and (2) potential trading partners are randomly encountered. In the literature, trading volume theoretical treatment arises in three settings about its relation to the bid and ask prices, price changes, and information (Karpoff, 1986). It is found that trading volume is negatively related to the bid and ask prices (Cohen, Maier, Schwartz, \& Whitcomb, 1979), positively related to the price change (Clark, 1973; Epps \& Epps, 1976; Tauchen \& Pitts, 1983), or noisily related to price change (Pfleiderer, 1984). Karpoff model (1986) has been used to investigate how information affects trading volume. Trading volume increases with the occurring of informational events and increasing the share number and these results, according to Karpoff (1986), are consistent with many empirical evidences on the price changes to trading volume relationship. According to Karpoff model, when trading volume increases, share prices decrease and aggregate information is not fully revealed by the market price (Pfleiderer, 1984). This is supported by Dontoh et al. (2004) and Liu and Liu (2007) who examined the influence of trading volume on the value relevance of the accounting information. The current paper adopted trading volume theory since it has a close relationship with the accounting information and share price.

\section{Hypotheses Development, Data Collection, and Models}

Few studies examined the influence of foreign ownership on the value relevance of accounting information focusing on earnings. While foreign ownership has a strong positive effect on the value relevance of earnings in Korea (Bae \& Jeong, 2007) and in Jordan (Anandarajan \& Hasan, 2010), the paper adds book value and cash flows to capture the influence of foreign ownership on the value relevance of these accounting variables simultaneously and indicate whether adding these variables will affect the results of Anandarajan and Hasan (2010) in Jordanian companies. The first hypothesis is divided into three sub-hypotheses in accordance with share price proxies as:

H1a: The value relevance of earnings, book value, and cash flows relative to average annual share price is greater for companies with foreign ownership.

H1b: The value relevance of earnings, book value, and cash flows relative to annual closing share price is greater for companies with foreign ownership.

H1c: The value relevance of earnings, book value, and cash flows relative to ATM-share price is greater for companies with foreign ownership.

Limited studies have examined the influence of trading volume on the value relevance of accounting information. These studies focused mainly on earning and book value. Trading volume has a significantly negative influence on the value relevance of earnings and book value (Dontoh et al., 2004), and it has an insignificant influence on the value relevance of these variables (Liu \& Liu, 2007). Since the influence of trading volume on the value relevance of cash flows has not been researched before particularly in Jordan, the paper extends the studies of Dontoh et al. (2004) and Liu and Liu (2007) by examining the influence of trading volume on the value relevance of earnings, book value and cash flows in Jordan to indicate whether adding this variable will affect the results of these studies. Since Clark (1973), Epps and Epps (1976) and Tauchen and Pitts (1983) have concluded a positive relationship between trading volume and change in share price, the paper hypothesizes a positive influence for trading volume on the value relevance of the accounting information. The second hypothesis is divided into three sub-hypotheses in accordance with share price proxies as:

H2a: The value relevance of earnings, book value, and cash flows relative to average annual share price is greater for companies with larger trading volume.

$\mathrm{H} 2 \mathrm{~b}$ : The value relevance of earnings, book value, and cash flows relative to annual closing share price is greater for companies with larger trading volume.

$\mathrm{H} 2 \mathrm{c}$ : The value relevance of earnings, book value, and cash flows relative to ATM-share price is greater for companies with larger trading volume.

Jordanian companies are selected as the research sample. Jordanian firms are particularly well suited for the study's empirical investigation for several reasons. First, this study is an extension for the previous valuation 
studies in this country. Second, Jordan has had stability in policies and practices in finance and accounting for a long time (Jordan Central Bank, 2009) which might support the reliability of the results of the current study. Third, since limited studies have examined the accounting disclosure in ASE (Al-Akra, Ali, \& Marashdeh, 2009) there is a need to focus more on scientific research in this area. In addition, Jordanian financial statements users' needs for accounting information should be taken into consideration for future research as accounting practices are affected by economic and technology changes which lead financial statements to lose their value relevance (Collins et al., 1997; Francis \& Schipper, 1999; Lev \& Zarowin, 1999; Oyerinde, 2009).

Although ASE was established in March 1999 and JSC in 2002, no complete data about the study's sample has been found before the year 2004. So, the year 2004 is considered to be the first financial year that has complete information about companies' financial statements, share prices and other information about the study's economic factors. Therefore the selected period of research sample is 6 years (2004-2009).

According to annual reports of JSC 2004-2009, Jordan has achieved many important developments within this period including a high economic growth, applying Accountancy Profession Law No. 73, establishing a high council for accounting and auditing, and setting up an improved Jordanian Association of Certified Public Accountants (JACPA). Although this has been considered as a significant step toward organizing the profession, its contents need to be updated along with new global developments (Rahman \& Waly, 2004). Within the period 2004 to 2009, the number of listed companies have increased from 192 to 272, market capitalization has increased from 13033.8 to 22526.9 in million Jordanian dinars, value traded from 3793.2 to 20318.1, average daily trading from 15.4 to 82.9 , and number of transactions from 1178.1 to 3780.9 (thousand).

Jordan was ranked $100^{\text {th }}$ with economic freedom score of 65.4 , making its economy the $51^{\text {st }}$ in 2009 index. Its score has increased by 1.3 points since 2008 , reflecting an increase in freedom in business, trade and government size where Jordan was ranked sixth out of the 17 countries in the Middle East/North Africa region. Investors should continue to execute due diligence in exploring investment opportunities and concluding purchases as they would in other countries (Dashti, 2011). In 2007, Jordan has been ranked the $5^{\text {th }}$ among the Middle East and North Africa region for doing business. This improvement is due to the reform policies adopted by Jordanian government. Nearly $71 \%$ of ASE companies showed consistent growth and profits (Doing Business, 2007).

Therefore, in Jordan, it is important to examine the influence of the two economic factors (foreign ownership and trading volume) on the value relevance of the three accounting variables (earnings per share, book value of equity per share and cash flows from operation per share). These five independent variables (IVs) are linked to the three share price proxies after controlling company's size and leverage. The paper uses share price in three different proxies as its dependent variables (DVs) to conduct whether the value relevance of these accounting variables could be affected by share price measurement. The three share price proxies are average annual share price, annual closing share price, and ATM-share price.

Sample selection is based on certain criteria of that the selected Jordanian companies must be listed in ASE, have complete information about their share prices, financial statements, and other information related to the variables within the selected period. The paper examines 91 companies per year (including 39 services companies and 52 industrial companies), with 910 observations per year (91 companies * 10 variables) and 5460 observations (910 observations *6 years).

The paper tests the relationships among its variables using the standard (simultaneous) multiple regression analysis. To assess the extent to which economic factors moderate the value relevance of the accounting information, the general price model is adopted.

$$
P=\beta_{0}+\beta_{1} E+\beta_{2} B V+\beta_{3} C F+e
$$

where

$\mathrm{P}=$ share price proxy (average annual share price (AP), annual closing share price $(\mathrm{CP})$ or share price a after three-month period following the financial year-end (ATMP) for a company in a year.

$\mathrm{E}=$ earnings per share for a company at the end of a year.

$\mathrm{BV}=$ book value of equity per share for a company at the end of a year.

$\mathrm{CF}=$ cash flows from operation per share for a company at the end of a year.

$\mathrm{e}=$ error term.

The paper employs a methodology similar to that in previous studies (Davis-Friday, Eng, \& Liu, 2006; Whelan, 2004; Dontoh et al., 2004; Liu \& Liu, 2007) that examined the influence of various economic factors on the value relevance of earnings and book value. As the value relevance of earnings, book value, and cash flows 
could be influenced by the economic factors, the coefficients on these accounting variables are functions of these factors as indicated by the dummy variables. An intercept dummy is also included in the model to assess the value relevance of the economic factors in their own right. To test the influence of the economic factors on the value relevance of accounting variables, the interaction term (accounting variable * economic factor) will be included in Eq. (1).

The paper adopted a model similar to that adopted by Whelan (2004), Lui and Lui (2007) and Habib and Weil (2008). Thus, the general model will be:

$$
P=\alpha_{0}+\alpha_{1} E F+\alpha_{2} E+\alpha_{3} E^{*} E F+\alpha_{4} B V+\alpha_{5} B V^{*} E F+\alpha_{6} C F+\alpha_{7} C F^{*} E F+e
$$

where:

$\mathrm{EF}=$ economic factor (foreign ownership or trading volume).

Coefficient $\alpha 1$ represents the value relevance of economic factor (foreign ownership or trading volume) in its own right. Coefficients $\alpha 2, \alpha 4$ and $\alpha 6$ represent the value relevance of earnings, book value, and cash flows respectively in the absence of the influence of economic factors. Coefficients $\alpha 2+\alpha 3, \alpha 4+\alpha 5$ and $\alpha 6+\alpha 7$ represent the share price response to earnings, book value, and cash flows respectively when they are influenced by economic factors.

In this model, earnings, book value, and cash flows are interacted with the selected economic factors to capture the influence of these factors on the value relevance of accounting information. According to Hartmann and Moers (1999), this model is assumed to be the suitable one by including the interaction term of a specific variable on the relationship between the dependent and independent variables. The interaction effect of various economic factors with the accounting information has been tested by many valuation studies using similar models (Davis-Friday et al., 2006; Hassan, 2004; Whelan, 2004; Dontoh et al., 2004; Francis, Schipper, \& Vincent, 2005; Liu \& Liu, 2007; Habib \& Weil, 2008; Shamki, 2012).

To examine the influence of the foreign ownership on the value relevance of earnings, book value, and cash flows, the sample has been categorized based on whether companies have foreign ownership. Following Anandarajan and Hasan (2010), this factor will be interacted with earnings, book value, and cash flows according to share price proxies. H1 models without and with control variables (company's size and leverage) are:

$$
\begin{gathered}
A P=\omega_{0}+\omega_{1} F O R N+\omega_{2} E+\omega_{3} E^{*} F O R N+\omega_{4} B V+\omega_{5} B V^{*} F O R N+\omega_{6} C F+\omega_{7} C F^{*} F O R N+e \\
A P=\omega_{0}+\omega_{1} F O R N+\omega_{2} E+\omega_{3} E^{*} F O R N+\omega_{4} B V+\omega_{5} B V^{*} F O R N+\omega_{6} C F+\omega_{7} C F^{*} F O R N+ \\
\omega_{8} S I Z E+\omega_{9} L E V R G+e \\
C P=\omega_{0}+\omega_{1} F O R N+\omega_{2} E+\omega_{3} E^{*} F O R N+\omega_{4} B V+\omega_{5} B V^{*} F O R N+\omega_{6} C F+\omega_{7} C F^{*} F O R N+e \\
C P=\omega_{0}+\omega_{1} F O R N+\omega_{2} E+\omega_{3} E^{*} F O R N+\omega_{4} B V+\omega_{5} B V^{*} F O R N+\omega_{6} C F+\omega_{7} C F^{*} F O R N+ \\
\omega_{8} S I Z E+\omega_{9} L E V R G+e \\
A T M P=\omega_{0}+\omega_{1} F O R N+\omega_{2} E+\omega_{3} E^{*} F O R N+\omega_{4} B V+\omega_{5} B V^{*} F O R N+\omega_{6} C F+\omega_{7} C F^{*} F O R N+e \\
A T M P=\omega_{0}+\omega_{1} F O R N+\omega_{2} E+\omega_{3} E^{*} F O R N+\omega_{4} B V+\omega_{5} B V^{*} F O R N+\omega_{6} C F+\omega_{7} C F^{*} F O R N+ \\
\omega_{8} S I Z E+\omega_{9} L E V R G+e
\end{gathered}
$$

where:

$\mathrm{AP}=$ average annual share price;

$\mathrm{CP}=$ annual closing share price;

$\mathrm{ATMP}=$ share price a after three-month period following the financial year-end;

FORN= dummy variable with value 1 for companies having foreign ownership at the end of financial year, 0 otherwise;

$\mathrm{SIZE}=\log$ of total assets;

LEVRG = ratio of debt to total assets; and

Other variables are defined before.

$\mathrm{H} 1 \mathrm{can}$ be stated in terms of the regression coefficients as H1: $\omega_{3}>0, \omega_{5}>0$, and $\omega_{7}>0$.

To examine the influence of trading volume on the value relevance of earnings, book value, and cash flows, the sample has been categorized based on whether companies have trading volume greater than the median trading volume of the sample. Median trading volume is represented by the median number of tradable shares that are held by companies' investors. Following Chen et al. (2001), this factor will be interacted with earnings, book value, and cash flows according to share price proxies. $\mathrm{H} 2$ models without and with control variables are: 


$$
\begin{gathered}
A P=\theta_{0}+\theta_{1} T R D V+\theta_{2} E+\theta_{3} E^{*} T R D V+\theta_{4} B V+\theta_{5} B V^{*} T R D V+\theta_{6} C F+\theta_{7} C F^{*} T R D V+e \\
A P=\theta_{0}+\theta_{1} T R D V+\theta_{2} E+\theta_{3} E^{*} T R D V+\theta_{4} B V+\theta_{5} B V^{*} T R D V+\theta_{6} C F+\theta_{7} C F^{*} T R D V+ \\
\theta_{8} S I Z E+\theta_{9} L E V R G+e \\
C P=\theta_{0}+\theta_{1} T R D V+\theta_{2} E+\theta_{3} E^{*} T R D V+\theta_{4} B V+\theta_{5} B V^{*} T R D V+\theta_{6} C F+\theta_{7} C F^{*} T R D V+e \\
C P=\theta_{0}+\theta_{1} T R D V+\theta_{2} E+\theta_{3} E^{*} T R D V+\theta_{4} B V+\theta_{5} B V^{*} T R D V+\theta_{6} C F+\theta_{7} C F^{*} T R D V+ \\
\theta_{8} S I Z E+\theta_{9} L E V R G+e \\
A T M P=\theta_{0}+\theta_{1} T R D V+\theta_{2} E+\theta_{3} E^{*} T R D V+\theta_{4} B V+\theta_{5} B V^{*} T R D V+\theta_{6} C F+\theta_{7} C F^{*} T R D V+e \\
A T M P=\theta_{0}+\theta_{1} T R D V+\theta_{2} E+\theta_{3} E^{*} T R D V+\theta_{4} B V+\theta_{5} B V^{*} T R D V+\theta_{6} C F+\theta_{7} C F^{*} T R D V+ \\
\theta_{8} S I Z E+\theta_{9} L E V R G+e
\end{gathered}
$$

where:

TRDV $=$ dummy variable with value 1 for companies with trading volume greater than median trading volume, 0 otherwise.

Other variables are defined before.

$\mathrm{H} 2$ can be stated in terms of the regression coefficients as: $\mathrm{H} 2: \theta_{3}>0, \theta_{5}>0$, and $\theta_{7}>0$.

The important multiple regression outputs are Adjusted $R^{2}$, ANOVA $F$ statistic, and t-test. Adjusted $R^{2}$ is a measure for the suitability of the correlation test results to evaluate the population. Adjusted $R^{2}$ helps in overestimating the association strength especially if the model has many IVs (Cavana et al., 2001) as in this study. $\quad F$-statistic is the value that is well known to most applied researchers. For practical purposes, this value indicates the significance of the test. Therefore, ANOVA $F$ statistic will be used to assess the statistical significance of a result in order to evaluate whether the model as a whole is significant (Pallant, 2007). $F$ statistic significance is depended upon in evaluating the study's models. The use of t-test in a regression model can help to determine the importance of each IV in the model. The best values are well below or above \pm 2 . If the significance of t-test is below the selected significant level, it means this IV will be retained in the regression equation. In value relevance studies, both betas coefficients and t-test are used to measure the strength of the value relevance (Klimczak, 2008).

Following previous value relevance studies (Whelan, 2004; Dontoh et al., 2004; Davis-Friday et al., 2006; Liu \&

\begin{tabular}{|c|c|c|c|c|c|c|c|c|c|c|c|}
\hline \multicolumn{2}{|c|}{ Statistics } & AP & $\mathrm{CP}$ & ATMP & E & BV & $\mathrm{CF}$ & FORN & TRDV & SIZE & LEVRG \\
\hline \multirow[t]{2}{*}{$\mathrm{N}$} & Valid & 546 & 546 & 546 & 393 & 545 & 347 & 546 & 546 & 546 & 546 \\
\hline & Missing & 0 & 0 & 0 & 153 & 1 & 199 & 0 & 0 & 0 & 0 \\
\hline \multicolumn{2}{|c|}{ Mean } & .3767 & .3501 & .3667 & -.8682 & .1671 & -.7387 & .84 & .45 & 7.2877 & .3030 \\
\hline \multicolumn{2}{|c|}{ Median } & .3456 & .3201 & .3222 & -.8539 & .1271 & -.6990 & 1.00 & 1.00 & 7.2400 & .2700 \\
\hline \multicolumn{2}{|c|}{ Std. Deviation } & .3358 & .3570 & .3555 & .5024 & .2225 & .5519 & .371 & .498 & .5677 & .2027 \\
\hline \multicolumn{2}{|c|}{ Skewness } & .496 & .334 & .481 & -.026 & .591 & -1.138 & -1.812 & .214 & .452 & .900 \\
\hline \multicolumn{2}{|c|}{ Std. Error of skewness } & .105 & .105 & .105 & .123 & .105 & .131 & .105 & .105 & .105 & .105 \\
\hline \multicolumn{2}{|c|}{ Kurtosis } & .421 & .654 & .691 & .124 & 3.131 & 5.665 & 1.287 & -1.961 & .200 & .640 \\
\hline \multicolumn{2}{|c|}{ Std. Error of kurtosis } & .209 & .209 & .209 & .246 & .209 & .261 & .209 & .209 & .209 & .209 \\
\hline \multicolumn{2}{|c|}{ Minimum } & -.52 & -.92 & -.57 & -2.00 & -.96 & -4.40 & 0 & 0 & 5.97 & .00 \\
\hline \multicolumn{2}{|c|}{ Maximum } & 1.55 & 1.56 & 1.80 & .57 & 1.19 & .89 & 1 & 1 & 8.95 & 1.08 \\
\hline
\end{tabular}
Liu, 2007; Anandarajan \& Hasan, 2010; Shamki, 2012), this study depends on betas, t-tests, and p-values for the pooled sample in accepting or rejecting the study's hypotheses.

\section{Results}

To make primary comparisons of the main differences among the study's variables, descriptive statistics are done as reported in Table 1. Although the maximum standard deviation value was reported for company's size and the minimum was for leverage, all values are less than 3 which ensures the absence of outliers. Most of skewness and kurtosis values are within \pm 2 which ensures the normal distribution of the sample.

Table 1. Descriptive statistics

All variables are defined before. 
The standard multiple regression analysis is used to test which IV (among a set of IVs) has the importance in explaining the variance in a DV. In standard regression, all variables are entered into the analysis and the effect of each IV on the DV is assessed after the variance from all other IVs had been accounted for. Each IV will be evaluated in terms of what it added to the prediction of the DV as specified from the regression equation. The influence of foreign ownership and trading volume on the value relevance of earnings, book value, and cash flows is tested relative to the three share price proxies with and without control variables.

Hypothesis (1) states that the value relevance of earnings, book value, and cash flows is greater for companies having foreign ownership. The influence of foreign ownership has been tested by the Equations $3 \mathrm{a}, \mathrm{b}, \mathrm{c}, \mathrm{d}$, e and f. Table 2 presents the regression results for the pooled sample with and without the company's size and leverage as control variables relative to the three share price proxies.

Table 2. Value relevance of $\mathrm{E}, \mathrm{BV}$ and $\mathrm{CF}$ influenced by foreign ownership relative to share price proxies

\begin{tabular}{|c|c|c|c|c|c|c|}
\hline \multicolumn{7}{|c|}{$\begin{aligned} \mathrm{P}= & \omega_{0}+\omega_{1} \mathrm{FORN}+\omega_{2} \mathrm{E}+\omega_{3} \mathrm{E} * \mathrm{FORN}+\omega_{4} \mathrm{BV}+\omega_{5} \mathrm{BV} * \mathrm{FORN}+\omega_{6} \mathrm{CF}+\omega_{7} \mathrm{CF} * \mathrm{FORN}+\mathrm{e} \\
\mathrm{P}= & \omega_{0}+\omega_{1} \mathrm{FORN}+\omega_{2} \mathrm{E}+\omega_{3} \mathrm{E} * \mathrm{FORN}+\omega_{4} \mathrm{BV}+\omega_{5} \mathrm{BV} * \mathrm{FORN}+\omega_{6} \mathrm{CF}+\omega_{7} \mathrm{CF} * \mathrm{FORN}+\omega 8 \mathrm{SIZE}+ \\
& \omega 9 \mathrm{LEVRG}+\mathrm{e}\end{aligned}$} \\
\hline \multirow{2}{*}{$\begin{array}{l}\text { P proxy } \\
\text { Statistics }\end{array}$} & \multicolumn{2}{|c|}{ AP } & \multicolumn{2}{|c|}{$\mathrm{CP}$} & \multicolumn{2}{|c|}{ ATMP } \\
\hline & Without CVs & With CVs & Without CVs & With CVs & Without CVs & With CVs \\
\hline$\omega_{1}$ & 0.25 & 0.14 & 0.29 & 0.19 & 0.19 & 0.06 \\
\hline t-test & $2.83^{* * *}$ & 1.49 & $3.29 * * *$ & $2.08 * *$ & $2.15^{* *}$ & 0.68 \\
\hline$\omega_{2}$ & 0.46 & 0.41 & 0.51 & 0.48 & 0.35 & 0.29 \\
\hline t-test & $10.22 * * *$ & $9.28 * * *$ & $11.93 * * *$ & $11.07 * * *$ & $7.29 * * *$ & $6.22 * * *$ \\
\hline$\omega_{3}$ & 0.31 & 0.28 & 0.34 & 0.31 & 0.16 & 0.13 \\
\hline t-test & $4.22 * * *$ & $3.83 * * *$ & $4.66^{* * *}$ & $4.31 * * *$ & $2.21 * *$ & $1.76^{*}$ \\
\hline$\omega_{4}$ & 0.57 & 0.58 & 0.58 & 0.59 & 0.54 & 0.53 \\
\hline t-test & $15.47 * * *$ & $14.85 * * *$ & $15.65 * * *$ & $15.24 * * *$ & $14.19 * * *$ & $13.30 * * *$ \\
\hline$\omega_{5}$ & 0.40 & 0.40 & 0.39 & 0.39 & 0.42 & 0.40 \\
\hline t-test & $6.30^{* * *}$ & $6.28 * * *$ & $6.34 * * *$ & $6.22 * * *$ & $6.62 * * *$ & $6.28 * * *$ \\
\hline$\omega_{6}$ & 0.23 & 0.24 & 0.28 & 0.29 & 0.23 & 0.23 \\
\hline t-test & $4.93 * * *$ & $5.01 * * *$ & $6.04 * * *$ & $6.27 * * *$ & $4.87 * * *$ & $5.05 * * *$ \\
\hline$\omega_{7}$ & 0.03 & -0.01 & 0.05 & 0.02 & 0.09 & 0.06 \\
\hline t-test & 0.47 & -0.16 & 0.93 & 0.41 & 1.50 & 0.97 \\
\hline$\omega_{8}$ & & 0.08 & & 0.03 & & 0.17 \\
\hline t-test & & $1.82 *$ & & 0.65 & & $3.73 * * *$ \\
\hline$\omega_{9}$ & & 0.05 & & 0.04 & & 0.000 \\
\hline t-test & & 1.12 & & 1.08 & & 0.01 \\
\hline $\operatorname{Adj} . R^{2}$ & 0.64 & 0.65 & 0.65 & 0.67 & 0.63 & 0.65 \\
\hline$F$ & $71.22 * * *$ & $56.94 * * *$ & $73.40^{* * *}$ & $57.57 * * *$ & $68.03 * * *$ & $55.65^{* * *}$ \\
\hline
\end{tabular}

Notes: $* * *$ and $* * *$ Significant at $10 \%, 5 \%$ and $1 \%$ levels.

$\mathrm{CVs}=$ control variables

Other variables are defined before.

However, according to average annual share price, annual closing share price and ATM-share price, the results show that the coefficients on foreign ownership $\left(\omega_{1}=0.25,0.29\right.$ and 0.19 respectively) are significant at 0.05 level or better. This demonstrates that foreign ownership is value relevant in its own right. According to average annual share price, annual closing share price and ATM-share price without control variables, the coefficients on 
earnings ( $\omega_{2}=0.46,0.51$ and 0.35 respectively), on book value ( $\omega_{4}=0.57,0.58$ and 0.54 respectively), and on cash flows $\left(\omega_{6}=0.23,0.28\right.$ and 0.23 respectively) are significant at 0.01 level and demonstrate the value relevance of earnings, book value, and cash flows in the absence of the influence of the foreign ownership. Foreign ownership shows significant influence on the value relevance of earnings and book value as demonstrated by the significant coefficients on the earnings interaction variable $\left(\omega_{3}=0.31,0.34\right.$ and 0.16 significant at 0.05 level or better) and book value interaction variable $\left(\omega_{5}=0.40,0.39\right.$ and 0.42 significant at 0.01 level) for those share price proxies respectively. Foreign ownership shows insignificant influence on the value relevance of cash flows as it is reflected by the insignificant coefficient on the interaction term $\left(\omega_{7}=0.03\right.$, 0.05 and 0.09 ) according to the three share price proxies respectively.

The sign of the coefficients on the interaction terms is consistent with Hypothesis 1 ( $a, b$ and c). Coefficients $\omega_{3}$, $\omega_{5}$ (and $\omega_{7}$ although it is insignificant) are positive, indicating an increase in the value relevance of the accounting information when foreign ownership is included. The coefficient on the interaction term for earnings is significant in the pooled sample and in two out of the six yearly regressions for average annual share price and annual closing share price, while it is significant in only one year for ATM-share price. The coefficient on the interaction term for book value is significant in the pooled sample and in the all yearly regressions for average annual share price and annual closing share price, while it is significant in five out of six yearly regressions for ATM-share price. The coefficient on the interaction term for cash flows is insignificant in the pooled sample and is significant in only one out of the six yearly regressions for the three share price proxies.

The results show that for companies with foreign ownership, the share price response to earnings is increased, as reflected in the positive coefficient on the earnings interaction term $\left(\omega_{3}\right)$. The reaction of average annual share price, annual closing share price, and ATM-share price to earnings increased from $0.46\left(\omega_{2}\right)$ to $0.77\left(\omega_{2}+\omega_{3}\right)$, 0.51 to 0.85 and from 0.35 to 0.51 respectively in the presence of foreign ownership. Share price response to book value is also increased, as reflected in the positive coefficient on the book value interaction term $\left(\omega_{5}\right)$. The reaction of those share price proxies to book value increased from $0.57\left(\omega_{4}\right)$ to $0.97\left(\omega_{4}+\omega_{5}\right), 0.58$ to 0.97 and from 0.54 to 0.96 respectively in the presence of foreign ownership. The three share price proxies show no response to cash flows in the presence of foreign ownership, as reflected in the insignificant coefficients on cash flows interaction term $\left(\omega_{7}\right)$. With the effect of this factor, closing share price proxy shows more response than the other share price proxies.

Including company's size and leverage as control variables in the regression model leads to stronger model's Adjusted $R^{2}$ and the relative importance and significance of the interaction terms remain the same (except that on earnings according to ATM-share price which became significant at 0.1 level). This increase in Adjusted $R^{2}$ values is largely attributable to an increase in the effect of the control variables. The significant $F$ statistic indicates that the model as a whole is significant.

Hypothesis (2) states that the value relevance of earnings, book value, and cash flows is greater for companies having larger trading volume. The influence of trading volume has been tested by the Equations $4 \mathrm{a}, \mathrm{b}, \mathrm{c}, \mathrm{d}$, e and f. Table 3 presents the regression results for the pooled sample with and without control variables relative to the three share price proxies.

However, according to average annual share price, annual closing share price, and ATM-share price, the results show that the coefficients on trading volume $\left(\theta_{1}=0.19,0.21\right.$ and 0.11 respectively) are insignificant which demonstrates that trading volume is irrelevant in its own right. According to average annual share price, annual closing share price, and ATM-share price without control variables, the coefficients on earnings $\left(\theta_{2}=0.46,0.51\right.$ and 0.35 respectively), on book value $\left(\theta_{4}=0.58,0.58\right.$ and 0.55 respectively), and on cash flows $\left(\theta_{6}=0.24,0.29\right.$ and 0.24 respectively) are significant at 0.01 level and demonstrate the value relevance of earnings, book value, and cash flows in the absence of the influence of trading volume. Trading volume shows significant influence on the value relevance of earnings, and book value as demonstrated by the significant coefficients on earnings interaction terms $\left(\theta_{3}=0.28,0.26\right.$ and 0.19 significant at 0.1 level or better) and on book value interaction terms $\left(\theta_{5}=0.32,0.32\right.$ and 0.34 significant at 0.05 level or better) for those share price proxies. Trading volume has insignificant influence on the value relevance of cash flows as it is reflected by the insignificant coefficient on the interaction term $\left(\theta_{7}=0.02,0.06\right.$ and 0.10$)$ according to those share price proxies respectively. 
Table 3. Value relevance of $\mathrm{E}, \mathrm{BV}$ and $\mathrm{CF}$ influenced by trading volume relative to share price proxies

\begin{tabular}{|c|c|c|c|c|c|c|}
\hline \multicolumn{7}{|c|}{$\begin{aligned} \mathrm{P}= & \theta_{0}+\theta_{1} \mathrm{TRDV}+\theta_{2} \mathrm{E}+\theta_{3} \mathrm{E} * \mathrm{TRDV}+\theta_{4} \mathrm{BV}+\theta_{5} \mathrm{BV} * \mathrm{TRDV}+\theta_{6} \mathrm{CF}+\theta_{7} \mathrm{CF} * \mathrm{TRDV}+\mathrm{e} \\
\mathrm{P}= & \theta_{0}+\theta_{1} \mathrm{TRDV}+\theta_{2} \mathrm{E}+\theta_{3} \mathrm{E} * \mathrm{TRDV}+\theta_{4} \mathrm{BV}+\theta_{5} \mathrm{BV} * \mathrm{TRDV}+\theta_{6} \mathrm{CF}+\theta_{7} \mathrm{CF} * \mathrm{TRDV}+\theta_{8} \mathrm{SIZE}+\theta_{9} \\
& \mathrm{LEVRG}+\mathrm{e}\end{aligned}$} \\
\hline \multirow{2}{*}{$\begin{array}{l}\text { P proxy } \\
\text { Statistics }\end{array}$} & \multicolumn{2}{|c|}{ AP } & \multicolumn{2}{|c|}{$\mathrm{CP}$} & \multicolumn{2}{|c|}{ ATMP } \\
\hline & Without CVs & With CVs & Without CVs & With CVs & Without CVs & With CVs \\
\hline$\theta_{1}$ & 0.19 & 0.13 & 0.21 & 0.15 & 0.11 & 0.02 \\
\hline t-test & 1.25 & 0.85 & 1.40 & 0.97 & 0.69 & 0.13 \\
\hline$\theta_{2}$ & 0.46 & 0.41 & 0.51 & 0.48 & 0.35 & 0.29 \\
\hline t-test & $10.23 * * *$ & $9.28 * * *$ & $11.92 * * *$ & $11.05 * * *$ & $7.34 * * *$ & $6.24 * * *$ \\
\hline$\theta_{3}$ & 0.28 & 0.27 & 0.26 & 0.25 & 0.19 & 0.17 \\
\hline t-test & $2.63 * * *$ & $2.55^{* *}$ & $2.42 * *$ & $2.33 * *$ & $1.72 *$ & 1.60 \\
\hline$\theta_{4}$ & 0.58 & 0.58 & 0.58 & 0.60 & 0.55 & 0.53 \\
\hline t-test & $15.71 * * *$ & $15.09 * * *$ & $15.86^{* * *}$ & $15.44 * * *$ & $14.37 * * *$ & $13.41 * * *$ \\
\hline$\theta_{5}$ & 0.32 & 0.27 & 0.32 & 0.27 & 0.34 & 0.27 \\
\hline t-test & $3.71 * * *$ & $3.10^{* * *}$ & $3.68 * * *$ & $3.08 * * *$ & $3.84 * * *$ & $3.08 * * *$ \\
\hline$\theta_{6}$ & 0.24 & 0.24 & 0.29 & 0.30 & 0.24 & 0.24 \\
\hline t-test & $5.01 * * *$ & $5.08^{* * *}$ & $6.09 * * *$ & $6.32 * * *$ & $4.90 * * *$ & $5.07 * * *$ \\
\hline$\theta_{7}$ & 0.02 & -0.003 & 0.06 & 0.04 & 0.10 & 0.07 \\
\hline t-test & 0.24 & -0.05 & 0.88 & 0.57 & 1.36 & 0.99 \\
\hline$\theta_{8}$ & & 0.08 & & 0.04 & & 0.18 \\
\hline t-test & & $1.79 *$ & & 0.79 & & $3.97 * * *$ \\
\hline$\theta_{9}$ & & 0.05 & & 0.04 & & -0.001 \\
\hline t-test & & 1.15 & & 0.96 & & -0.03 \\
\hline Adj. $R^{2}$ & 0.64 & 0.65 & 0.67 & 0.67 & 0.63 & 0.65 \\
\hline$F$ & $49.35^{* * *}$ & $40.87 * * *$ & $48.34 * * *$ & $40.21 * * *$ & $45.78 * * *$ & $41.55 * * *$ \\
\hline
\end{tabular}

Notes: *,** and $* * *$ Significant at $10 \%, 5 \%$ and $1 \%$ levels.

All variables are defined before.

The sign of the coefficients on the interaction terms is consistent with Hypothesis 2 ( $a, b$ and $c$ ). Coefficients $\theta_{3}$, $\theta_{5}$ (and $\theta_{7}$ although it is insignificant) are positive, indicating an increase in the value relevance of the accounting information when a company has larger trading volume. The coefficient on the interaction term for earnings is significant in the pooled sample and in two out of the six yearly regressions for average annual share price and annual closing share price, while it is significant in only one year for ATM-share price. The coefficient on the interaction term for book value is significant in the pooled sample and in only one year out of the six yearly regressions for average annual share price and ATM-share price, while it is insignificant for all yearly regressions for annual closing share price. The coefficient on the interaction term for cash flows is insignificant in the pooled sample. It is significant in two out of the six yearly regressions for ATM-share price, while it is insignificant for the six yearly regressions for average annual share price and annual closing share price.

The results of Table 3 show that for companies with larger trading volume, share price response to earnings is increased, as reflected in the positive coefficient on the earnings interaction term $\left(\theta_{3}\right)$. The reaction of average annual share price, annual closing share price and ATM-share price to earnings increased from $0.46\left(\theta_{2}\right)$ to 0.74 $\left(\theta_{2}+\theta_{3}\right), 0.51$ to 0.77 and from 0.35 to 0.54 respectively in the presence of trading volume. Share price response to book value is also increased, as reflected in the positive coefficient on the book value interaction term $\left(\theta_{5}\right)$. The reaction to book value increased from $0.58\left(\theta_{4}\right)$ to $0.90\left(\theta_{4}+\theta_{5}\right)$ for both average annual share price and annual closing share price and from 0.55 to 0.89 for ATM-share price in the presence of trading volume. The 
three share price proxies show no response to cash flows in the presence of trading volume, as reflected in the insignificant coefficients on the cash flows interaction term $\left(\theta_{7}\right)$. With the effect of this factor, closing share price proxy shows more response than the other share price proxies.

The results show that including company's size and leverage as control variables in the regression model leads to stronger model's Adjusted $R^{2}$. The relative importance and significance of the interaction terms remain the same (except that on earnings according to ATM-share price which became insignificant). This increase in Adjusted $R^{2}$ values is largely attributable to an increase in the effect of the control variable. The significant $F$ statistic indicates that the model as a whole is significant.

\section{Discussion and Summary}

The paper investigated whether the economic factors affected the value relevance of earnings, book value, and cash flows. The influence of foreign ownership and trading volume as economic factors has been tested in order to capture the moderating effect of these factors on the value relevance of accounting variables in Jordan. This influence has been tested according to the three share price proxies with and without the control variables.

Results from testing Hypothesis (1) show that foreign ownership has a significant positive influence on the value relevance of earnings and book value as demonstrated by the significant positive coefficients on the interaction variables $\left(\omega_{3}\right.$ and $\left.\omega_{5}\right)$, indicating (as it is expected) an increase in the value relevance of earnings and book value for companies having foreign ownership. The result on earnings is consistent with previous studies (Bae \& Jeong, 2007; Anandarajan \& Hasan, 2010; Shamki, 2012) in Korea and Jordan respectively. This result could be explained by foreign investment theory, which states that foreign ownership has a significant effect on firm value by improving its performance. Theoretically, it is found that higher proportion of foreign ownership has positive association with company's performance because it introduces advanced information technology and leads to greater economic efficiency (Claessens et al., 2001; Okuda \& Rungsomboon, 2004; Anandarajan \& Hasan, 2010).

The results also show that foreign ownership has insignificant influence on the value relevance of cash flows as it is demonstrated by the insignificant coefficients on the interaction variable $\left(\omega_{7}\right)$. This result is unexpected and it might be explained by that the predictive ability of cash flows is lower than that of earnings and book value (Wilson, 1986; Dechow, 1994; Barth, 2000; Thi \& Schultze, 2009), therefore, market participants rely more on earnings and book value than on cash flows. Another explanation is that cash flow is not a necessary figure for accounting principles to be based on (Hadi, 2005; Velez-Parega, 2005), thus affecting its value relevance.

While the influence of foreign ownership on the value relevance of earnings has been researched in prior studies, its influence on the value relevance of book value and cash flows has not been well researched. Therefore, a comparison between the current results regarding book value and cash flows with any prior studies is unavailable. Finally, Hypothesis (1) results show that the value relevance of earnings and book value relative to the three share price proxies is greater $\left(\omega_{3}>0, \omega_{5}>0\right)$ for companies having foreign ownership in Jordan, while this factor has no significant influence on the value relevance of cash flows $\left(\omega_{7}=0\right)$. This leads to accept Hypothesis (1) for earnings and book value but not for cash flows.

The results of Hypothesis (2) show that trading volume has a significant positive influence on the value relevance of earnings and book value. This is demonstrated by the significant positive coefficients on the interaction variables $\left(\theta_{3}\right.$ and $\left.\theta_{5}\right)$, indicating an increase in their value relevance for companies with larger trading volume. The result is inconsistent with the results of Dontoh et al. (2004) and Liu and Liu (2007) and it might be explained by the trading volume theory, which states that trading volume is positively related to the price change (Clark, 1973; Epps \& Epps, 1976; Tauchen \& Pitts, 1983) and in turn to the value relevance of earnings and book value.

The results also show insignificant influence for trading volume on the value relevance of cash flows as it is reflected by the insignificant coefficients on the interaction variable $\left(\theta_{7}\right)$, indicating that trading volume did not affect the value relevance of cash flows. While the influence of trading volume on the value relevance of earnings and book value has been researched in prior studies, its influence on the value relevance of cash flows has not. Therefore, a comparison between the results related to cash flows with any prior studies is unavailable.

The results of Hypothesis (2) are inconsistent with that of previous studies. This inconsistency might be explained by; (1) share prices are led by financial statements information that captures the intrinsic share values toward which share prices drift. Then the value relevance would be represented by profits generated from executing accounting-based trading rules (Ou \& Penman, 1989: Harris \& Ohlson, 1990), (2) it may be just for the observed period (2004-2009) in ASE, (3) trading volume has significant and positive effect on share price 
could be the real pattern or (4) adding cash flows as a new variable has changed the trend of the prior results. Therefore, future studies are called to extend the sample's size and period in order to investigate this extraordinary phenomenon and enrich the literature with more evidences about the influence of this factor on the value relevance of the accounting information.

Finally, the results of Hypothesis (2) show that the value relevance of earnings and book value relative to the three share price proxies is greater $\left(\theta_{3}>0, \theta_{5}>0\right)$ for companies having larger trading volume, while this factor has no significant influence on the value relevance of cash flows $\left(\theta_{7}=0\right)$. This leads to accept Hypothesis (2) for earnings and book value but not for cash flows.

The paper offers practical contributions to market participants including investors, managers, and financial analysts in addition to its contributions to the academia and regulatory bodies. The results might assist investors to (1) better understand company's real financial position by manipulating the asymmetric information and (2) improve the control of managers' performance results which is considered in making investment decisions. Furthermore, while many studies focus on examining the value relevance of earnings and book value, the current paper examined the moderating effect of the economic factors on the value relevance of the accounting information. Based on the findings of this paper, market participants might be able to conclude the firm value through the company's foreign ownership and trading volume.

Since the widely used valuation model is employed to determine the value relevance of accounting information, primarily earnings and book value, one major implication of the current paper is extending the valuation model by including cash flows as limited studies investigated the value relevance of this variable together with earnings and book value. The study's developed models present a tool for indicating whether or not firm value can be predicted from its accounting information and what economic factors could more influence this prediction. This could be useful as a primary tool to assess the financial statements completeness.

Using data from Jordan contributes to the valuation literature as this paper concluded similar findings with that from prior research using data from US, UK and other developed countries which reflected the ability of these findings to be generalized to different markets.

This paper provides empirical evidence about the indirect influence of the selected economic factors on the market. Accordingly, it presents support for future regulator activity that tends to effectively monitor management in order to enhance the complimentary of the reporting process. This will improve the market participants' ability to make their right decisions about market distribution.

The findings could be relevant for the courses, such as financial statements analysis and accounting theory and practice. In financial statements analysis courses, valuation model mainly focused on earnings. The paper presents further evidence of the importance of book value as this variable shows significant and positive relationships with the three share price proxies, indicating a significant link between the accounting information integrity and the information usefulness to market participants.

The paper attempted to include only companies with available data for the selected six years (2004-2009). The small sample size and observations is due to that (1) some companies that are registered before 2004 were dropped from the analysis due to missing data (outliers), (2) many new companies with complete data which are supposed to be the target of this paper have been excluded due to their recent registration date (registered after 2004) and (3) companies that are listed in banking, insurance, and financial industries have been excluded. The problem of the small sample size and observations has been addressed in this paper by pooling the data to evaluate the results.

Future research has to be extended to examine the influence of different economic factors on the value relevance of accounting information which may provide new insights of the possible factors that could influence the value relevance of accounting information. Future research is called to extend sample size and period and examine the value relevance of the accounting information in a comparison with that from across countries in Middle East or with other regions. This may provide the generalizability of the results of the value relevance. In addition to price models, return models might be used in future research to compare the value relevance of accounting information conducted from the two models especially in Jordan.

\section{Acknowledgement}

The author wishes to present his thanks for the valuable comments from Assoc. Prof. Dr. Azhar Abdul Rahman, College of Business-University Utara Malaysia. Thanks to Cihan University Sulaimaniya/Sulaimaniya- Iraq for its financial support. 


\section{References}

Admati, A. R., \& Pfleiderer, P. (1988). A theory of intraday patterns: Volume and price variability. Review of Economic Studies, 1(1), 3-40. Retrieved from http://www.jstor.org/stable/2962125

Al-Akra, M., Ali, M., \& Marashdeh, O. (2009). Development of accounting regulation in Jordan. The International Journal of Accounting, 44(2), 163-186. http://dx.doi.org/10.1016/j.intacc.2009.03.003

Aliber, R. Z. (1971). The multinational enterprise in a multi currency world. In J. H. Dunning (ed.), The multinational enterprise. London: Allen and Unwin.

Amman Stocks Exchange (ASE). Annual reports (2000-2009). Retrieved from http://www.ase.com.jo/ar/announcement.php?cat=F.S

Anandarajan, A., \& Hasan, I. (2010). Value relevance of earnings: Evidence from Middle Eastern and North African countries. Advances in Accounting, Incorporating Advances in International Accounting, 26(2), 270-279. http://dx.doi.org/10.1016/j.adiac.2010.08.007

Bae, K. H., \& Jeong, S. W. (2007). The value relevance of earnings, book value, ownership structure, and business group affiliation: Evidence from Korean business groups. Journal of Business Finance and Accounting, 34(5-6), 740-766. http://dx.doi.org/10.1111/j.1468-5957.2007.02017.x

Bamber, L. (1986). The information content of annual earnings releases: A trading volume approach. Journal of Accounting Research, 24(1), 40-56. http://dx.doi.org/10.2307/2490803

Bamber, L., \& Cheon, Y. (1995). Differential price and volume reactions to accounting earnings announcements. The Accounting Review, 70(3), 417-441. Retrieved from http://www.jstor.org/stable/248532

Barron, O. E. (1995). Trading volume and belief revisions that differ among individual analysts. The Accounting Review, 70(4), 581-597. Retrieved from http://www.jstor.org/stable/248248

Barth, M. (2000). Valuation-based accounting research: Implications for financial reporting and opportunities for future research. Accounting and Finance, 40, 7-31. http://dx.doi.org/10.1111/1467-629X.00033

Beaver, W. (1968). The information content of annual earnings announcements. Empirical research in accounting. Journal of Accounting Research, 6, 7-92. http://dx.doi.org/10.2307/2490070

Bhattacharya, N. (2001). Investors' trade size and trading responses around earnings announcements: An empirical investigation. The Accounting Review, 76(2), 221-244. Retrieved from http://dx.doi.org/10.2308/accr.2001.76.2.221

Boubakri, N., Cosset, J., \& Guedhami, O. (2005). Postprivatization corporate governance: The role of ownership structure and investor protection. Journal of Financial Economics, 76, 369-399. http://dx.doi.org/10.1016/j.jfineco.2004.05.003

Bronars, S. G., \& Deere, D. R. (1991). The threat of unionization, the use of debt and the preservation of shareholder wealth. Quarterly Journal of Economics, 106(1), 231-254. http://dx.doi.org/10.2307/2937914

Callahan, C., Lee, C., \& Yohn, T. (1997). Accounting disclosures and information asymmetry: Research opportunities associated with bid-ask spreads. Accounting Horizons, 13, 50-60.

Casson, M. (1985). The theory of foreign direct investment. In J. Peter, Buckley, and Mark Casson (Eds.), The economic theory of the multinational enterprise. London: Macmillan.

Cavana, R. Y., Delahaye, B. L., \& Sekaran, U. (2001). Applied business research: Qualitative and quantitative methods. John Wiley and Sons, Inc.

Chen, C., Chen, S., \& Su, X. (2001). Is accounting information value-relevant in the emerging Chinese stock market. Journal of International Accounting, Auditing and Taxation, 10, 1-22. http://dx.doi.org/10.1016/S1061-9518(01)00033-7

Claessens, S., Demirgüç-Kunt, A., \& Huizinga, H. (2001). How does foreign entry affect domestic banking markets? Journal of Banking and Finance, 25, 891-911. http://dx.doi.org/10.1016/S0378-4266(00)00102-3

Clark, P. K. (1973). A subordinated stochastic process model with finite variance for speculative prices. Econometrica, 41(1), 135-55. http://dx.doi.org/10.2307/1913889

Cohen, K., Maier, F. S., Schwartz, R. A., \& Whitcomb, D. K. (1979). Market makers and the market spread: A review of recent literature. Journal of Financial and Quantitative Analysis, 14, 813-35. http://dx.doi.org/10.2307/2330456 
Collins, D., Maydew, E., \& Weiss, I. (1997). Changes in the value-relevance of earnings and book values over the past forty years. Journal of Accounting and Economics, 24, 39-67. http://dx.doi.org/10.1016/S0165-4101(97)00015-3

Covrig, V., Lau, S. T., \& Ng, L. (2006). Do domestic and foreign fund managers have similar preferences for stock characteristics? A cross-country analysis. Journal of International Business Studies, 37(3), 407-429. http://dx.doi.org/10.1057/palgrave.jibs.8400195

Cready, W. M., \& Mynatt, P. G. (1991). The information content of annual reports: A price and trading response analysis. The Accounting Review, 66, 291-312. Retrieved from http://www.jstor.org/stable/247755

Dahawy, K. (2009). Company characteristics and disclosure level the Egyptian story. Company characteristics and disclosure level: The case of Egypt. International Research Journal of Finance and Economics, 34, 194-208.

Damodaran, A. (2007). Valuation approaches and metrics: A survey of the theory and evidence. John Wiley and Sons Inc.

Dashti, S. (2011). Trade information packet and water industry report. Publications of the World Trade Center, San Diego.

Davis-Friday, P., Eng, L., \& Liu, C. (2006). The effects of the Asian crisis, corporate governance and accounting system on the valuation of book value and earnings. The International Journal of Accounting, 41(1), 22-40. http://dx.doi.org/10.1016/j.intacc.2005.12.002

Dechow, P. (1994). Accounting earnings and cash flows as measures of firm performance: The role of accounting accruals. Journal of Accounting and Economics, 18(1), 3-42. http://dx.doi.org/10.1016/0165-4101(94)90016-7

Doing Business. (2007). The international report. USA, Washington.

Dontoh, A., Radhakrishnan, S., \& Ronen, J. (2004). The declining value relevance of accounting information and non-information-based trading: An empirical analysis. Contemporary Accounting Research, 21(4), 795-812. http://dx.doi.org/10.1506/J6P4-2UYP-HFXY-RBT1

Dyer, J. C., \& McHugh, A. J. (1975). The timeliness of the Australian annual report. Journal of Accounting Research, 13(2), 204-219. http://dx.doi.org/10.2307/2490361

Enthoven, A. J. (1985). Accounting in developing countries. In C. W. Nobes \& R. H. Parker (Eds.), Comparative International Accounting. Oxford: Philip Allan.

Epps, T. W., \& Epps, M. L. (1976). The stochastic dependence of security price changes and transaction volumes: Implications for the mixture-of-distribution hypothesis. Econometrica, 44, 305-21. http://dx.doi.org/10.2307/1912726

Felthman, G., \& Ohlson, J. (1995). Valuation and clean surplus accounting for operating and financial activities. Contemporary Accounting Research, 11(2), 689-731. http://dx.doi.org/10.1111/j.1911-3846.1995.tb00462.x

Francis, J., \& Schipper, K. (1999). Have financial statements lost their relevance? Journal of Accounting Research, 37(2), 319-352. http://dx.doi.org/10.2307/2491412

Francis, J., Schipper, K., \& Vincent, L. (2005). Earnings and dividend informativeness when cash flow rights are separated from voting rights. Journal of Accounting and Economics, 39, 329-360. http://dx.doi.org/10.1016/j.jacceco.2005.01.001

Habib, A., \& Weil, W. (2008). The influence of regulatory reform on the value-relevance of accounting information: Evidence from the 1993 regulatory reforms in New Zealand. Advances in Accounting, incorporating Advances in International Accounting, 24, 227-236.

Hadi, M. (2005). Information content of cash flows data: Evidence for Jordon. Working paper, Kuwait University.

Harris, M., \& Raviv, A. (1993). Difference of opinion make a horse race. Review of Financial Studies, 6, 473-506. http://dx.doi.org/10.1093/rfs/6.3.473

Harris, T., \& Ohlson, J. (1990). Accounting disclosures and the market's valuation of oil and gas properties: Evaluation of market efficiency and functional fixation. The Accounting Review, 65, 764-780. Retrieved from http://www.jstor.org/stable/247649

Hartmann, F., \& Moers, F. (1999). Testing contingency hypotheses in budgetary research: an evaluation of the 
use of moderated regression analysis. Accounting, Organizations and Society, 24, 291-315. http://dx.doi.org/10.1016/S0361-3682(99)00002-1

Hassan, M. S. (2004). The information quality of derivative disclosures in corporate annual reports of Australian firms in the extractive industries. Ph.D. thesis. School of Accountancy at Queensland University of Technology.

Iversen, C. (1935). Aspects of international capital movements. London, Copenhagen: Levin and Munksgaard.

Jordan Central Bank. (2009). Report of Jordanian finance sector stability. Retrieved from http://www.cbj.gov.jo/arabic/index.php

Jordan Securities Commission (JSC). Annual reports of JSC, 2004-2009. Retrieved from http://www.jsc.gov.jo

Kandel, E., \& Pearson, N. (1995). Differential interpretations of public signals and trade in speculative markets. Journal of Political Economy, 103, 831-872. http://dx.doi.org/10.1086/262005

Kang, J., \& Stulz, R. (1997). Why is there a home bias? An analysis of foreign portfolio equity ownership in Japan. Journal of Financial Economics, 46, 3-28. http://dx.doi.org/10.1016/S0304-405X(97)00023-8

Karpoff, J. M. (1986). A theory of trading volume. The Journal of Finance, 41(5), 1069-1087. http://dx.doi.org/10.1111/j.1540-6261.1986.tb02531.x

Kim, J., \& Yoo, S. S. (2009). Market liberalization and foreign equity portfolio selection in Korea. Journal of Multinational Financial Management, 19, 206-220. http://dx.doi.org/10.1016/j.mulfin.2008.11.003

Kim, O., \& Verrecchia, R. E. (1991). Market reactions to anticipated announcements. Journal of Financial Economics, 30, 273-309. http://dx.doi.org/10.1016/0304-405X(91)90033-G

Kim, O., \& Verrecchia, R. E. (2001). The relation among disclosure, returns, and trading volume information. The Accounting Review, 76(4), 633-654. http://dx.doi.org/10.2308/accr.2001.76.4.633

Klimczak, K. M. (2008). Testing value relevance of accounting earnings: Theory and method, general accounting theory: Evaluation and design for efficiency. Górowski, WAiP, 361-374.

Kothari, S. P. (2000). The role of financial reporting in reducing financial risks in the market. In E. S. Rosengren, \& J. S. Jordan (Eds.), Building an infrastructure for financial stability. Federal Reserve Bank of Boston Conference Series No. 44, 89-102.

Lev, B., \& Zarowin, P. (1999). The boundaries of financial reporting and how to extend them. Journal of Accounting Research, 37, 353-385. http://dx.doi.org/10.2307/2491413

Liu, J., \& Liu, C. (2007). Value relevance of accounting information in different stock market segments: The case of Chinese A, B, and H-Shares. Journal of International Accounting Research, 6(2), 55-81. http://dx.doi.org/10.2308/jiar.2007.6.2.55

Matsa, D. A. (2010). Capital structure as a strategic variable: Evidence from collective bargaining. The Journal of Finance, 65(3), 1197-1232. http://dx.doi.org/10.1111/j.1540-6261.2010.01565.x

Myers, S. C., McConnell, J., Peterson, A., Soter, D., \& Stern, J. (1998). Vanderbilt University roundtable on the capital structure puzzle. Journal of Applied Corporate Finance, 11(1), 8-24. http://dx.doi.org/10.1111/j.1745-6622.1998.tb00073.x

Ohlson, J. (1995). Earnings, book values, and dividends in equity valuation. Contemporary Accounting Research, 11(2), 661-687. http://dx.doi.org/10.1111/j.1911-3846.1995.tb00461.x

Okuda, H., \& Rungsomboon, S. (2004). Comparative cost study of foreign and Thai domestic banks 1990-2002: Estimating cost functions of the Thai banking industry. CEI Working Paper Series.

Ota, K. (2001). The value-relevance of book value, current earnings, and management forecasts of earnings. Working paper, Musashi University.

Ou, J., \& Penman, S. (1989). Accounting measurement, price-earnings ratios, and the information content of security prices. Journal of Accounting Research, 27, 111-152. http://dx.doi.org/10.2307/2491068

Oyerinde, D. T. (2009). Value relevance of accounting information in emerging stock market: The case of Nigeria. Proceedings of the $10^{\text {th }}$ Annual Conference (C2009 IAABD, Repositioning African Business and Development for the $21^{\text {st }}$ Century Simon Sigué (Ed.), 9-14.

Pallant, J. (2007). SPSS survival manual (3rd ed.). McGraw Hill Education.

Pfleiderer, P. (1984). The volume of trade and the variability of prices: A framework for analysis in noisy 
rational expectations equilibria. Working paper, Stanford University.

Rahman, Z., \& Waly, H. (2004). Report on the observance of standard and codes, ROCS. Hashemite Kingdom of Jordan, Publication of World Bank. Retrieved from www.worldbank.org/ifa/rosc_aa_jor.pdf

Sethi, D., Guisinger, S. E., Phelan, S. E., \& Berg, D. M. (2003). Trends in foreign direct investment flows: A theoretical and empirical analysis. Journal of International Business Studies, 34(4), 315-326. http://dx.doi.org/10.1057/palgrave.jibs.8400034

Shamki, D. (2012). Impact of non accounting information on the value relevance of accounting information: The case of Jordan. International Journal of Business and Social Research, 1(2), 9-24. http://dx.doi.org/10.5539/ijbm.v7n3p133

Staley, E. (1935). War and the private investor. New York: Doubleday Doran and Company Inc.

Tauchen, G., \& Pitts, M. (1983). The price variability-volume relationship on speculative markets. Econometrica, 51, 485-505. http://dx.doi.org/10.2307/1912002

Thi, T. D., \& Schultze, W. (2009). Capitalizing research and development (R\&D): The incremental information content of accruals vs. cash flows for German firms. Working paper, University of Augsburg.

Varian, H. R. (1989). Differences of opinion in financial markets. In Courtenay C. Stone (Ed.), Financial risk: Theory, evidence and implications. proceedings of the eleventh annual economic policy conference of the Federal Reserve Bank of St. Louis, Kluwer, Boston.

Velez-Parega, I. (2005). Once more, the correct definition for the cash flows to value firm (free cash flow and cash flow to equity). Working paper, Universidad Tecnologica de Bolivar.

Verrecchia, R. E. (2001). Essays on disclosure. Journal of Accounting and Economics, 32, 97-180. http://dx.doi.org/10.1016/S0165-4101(01)00025-8

Verwijmeren, P., \& Derwall, J. (2010). Employee well-being, firm leverage and bankruptcy risk. Journal of Banking and Finance, 34, 956-964. http://dx.doi.org/10.1016/j.jbankfin.2009.10.006

Vishnani, S., \& Shah, B. (2008). Value relevance of published financial statements with special emphasis on impact of cash flow reporting. International Research Journal of Finance and Economics, 17, 84-90.

Whelan, C. (2004). The impact of earnings management on the value-relevance of earnings and book value: A comparison of short-term and long-term discretionary accruals. A Ph.D. thesis, Faculty of Business, Bond University, Australia.

Wilson, P. (1986). The relative information content of accruals and cash flows: Combined evidence at the earnings announcement and annual report release date. Journal of Accounting Research, 24, 165-200. http://dx.doi.org/10.2307/2490736 